\title{
The Concept of Liberty in a World of Porous Borders
}

\author{
John Christman \\ Professor of Philosophy, Political Science, and Women's Studies \\ Penn State University
}

American Political Science Association, September 2020

In the various analyses of the concept of freedom in the political and philosophical literature, it is striking how distant these accounts are from the language of freedom that seems most prominent in political discourse, namely in struggles for liberation and resistance to oppression. From abolitionist speeches and literature, to contemporary efforts to escape enslavement, tyranny and economic deprivation, referring to the aims of such efforts as a freedom struggle is enormously common. Yet, most accounts of liberty or freedom - negative liberal views, neo-republican accounts, and many positive conceptions - fail to adequately account for the meaning of freedom in these contexts in crucial ways. This is either because they assume that the subject of freedom is a recognized member (citizen) of a functioning democracy and/or that the only institutional setting in which freedom can be enjoyed is a relatively idealized (just) polity.

However, refugees, migrants, the enslaved, and those suffering under oppressive regimes can be said to struggle for a kind of freedom that cannot presuppose such conditions. Either they search for a life in a host country in which they are not (and do not aspire to be) full citizens, or their only realistic objective in their journeys is to find protection in a political setting that is far from ideal. If we want to use the language of freedom to describe the aims of such struggles, then either we view such freedom struggles as entirely quixotic or we need to understand that concept in ways that are more nuanced than is typically found in the literature, or so I want to argue.

A motivating point for my discussion is to take seriously the abundant aspects of our current and historical condition that depart radically from the simplified assumptions of (relatively) ideal social and political theory. For instance, it is instructive to note that arguably no current state conforms fully to the parameters of standard theories of justice and democracy, or at least that a majority of people in the world do not live in such a state. Even functioning democracies in the developed world are woefully short of these ideals, and those who live in conditions of tyranny, occupation, and repression seek escape from those conditions without an expectation that such an escape will find them in perfectly just political settings. Also, countless persons who have emigrated from their home countries, fled persecution, disaster, and the like reside in conditions that do not afford them citizenship status and may not hold out much hope that they will be so afforded in their lifetimes. Indeed, many of those in such communities do not aspire to be given regular citizenship in their host countries, but rather seek different sorts of legal protections and community support. Must our conceptions of freedom be such that none of these types of individuals or groups can be labeled free? If their flight from earlier brutish conditions can be described as a search for freedom, will they never attain it?

In this essay, I will use these observations as a spring board for an argument that we need an account of freedom that captures the aspirations and struggles of such persons and groups under a relatively realistic description of current conditions. Since many standard accounts of freedom tie that idea conceptually to membership in a stable, just (or nearly-just) state, the 
discourse surrounding the plight of many people searching for "freedom" who are not and do not aim to be such members is not adequately captured. ${ }^{1}$

This is an especially poignant issue for many conceptions of liberty that lie in the "positive" terrain, since that conception often cashes out in terms of self-government and, by extension, to citizenship in self-governing polities. I will suggest, however, that the kind of selfgovernment required by freedom (seen as the object of liberation struggles) need not entail full citizenship in a fully functioning democracy. This is in part because less formal, social practices rather than political participation form the contours of social life that constitutes the selfgovernment of many people. What is needed, I will claim is an account of basic freedom in a positive mode, an idea that lives up to the conceptual and normative requirements of such a concept and which can apply to those groups who do not enjoy (and may not seek) citizenship in their resident country. I will attempt to sketch such an idea.

\section{Non-Ideal Conditions and the Context of Freedom Discourse}

Traditionally, political theorizing and the conceptual analysis of the key concepts central to it has proceeded as if such concepts applied to relatively settled, closed, and well-ordered societies. However, increasingly in recent decades, greater attention to the decidedly non-ideal conditions of the social world has been in evidence. This is motivated by the observation that ignoring actual facts of victimization and the effects of injustice can serve to mis-describe the persons, interests, and social dynamics relevant to those concepts and the principles in which they function. Further, the dynamics of public discourse in the real world shapes our intuitions about what such normative concepts must mean, so abstracting from the historical and ongoing conflicts in which such discourse operates can distort our modeling of those ideas and principles. And insofar as the rationale for developing such principles is to guide critique and reform (or resistance and rebellion perhaps) - that is, those "pressing concerns" Rawls mentions - such idealized principles fail to appeal to members of actual societies who don't meet the criteria of persons described in abstract models. ${ }^{2}$

This is especially significant in the case of a concept like freedom, if only because that idea is so central to struggles against intolerable and oppressive conditions around the world and throughout history. The abolitionist movement in the antebellum U.S., to site only one obvious example, proceeded with ubiquitous reference to "freedom" as set against the condition of enslavement. Now granted, those ideas referred to codified legal distinctions that garnered their meaning from established laws and institutions. Still, the idea of freedom should be explicated in ways that make sense of the language of those anti-oppressive struggles, which of course continue on today even if legalized chattel slavery has been abolished.

This observation also highlights the ways that discussions of concepts like freedom assume that the backdrop against which that characteristic is enjoyed is a functioning state, presumably a constitutional democracy in which the subject of freedom is a citizen. But one key aspect of the current condition that motivates rethinking of the idea of liberty here concerns the precarious status that countless persons have or hope to have regarding citizenship in fully functioning democracies. Large scale and recurrent migration is now a permanent aspect of most societies, where it is reported that the number of international migrants reached 272 million

\footnotetext{
1 I will also argue that value-neutral negative accounts of liberty may escape this implication, but these views fail to capture the plight and aims of refugees (etc.) for other reasons.

2 For discussion see Simmons 2010, Stemplowska 2008, and Mills 2005.
} 
people in 2019, up from 153 million in $1990 .^{3}$ An estimated 2.9 percent of the world's population live outside of the country of their birth, many without citizenship status in their host countries. Moreover, according to the U.N., at the end of 2016 there were more than 65 million people forced from home by conflict and persecution. Among them are nearly 22.5 million refugees and another 10 million stateless people who have been denied a nationality and basic rights such as education, healthcare, employment and freedom of movement. ${ }^{4}$ Their initial escape from conditions of violence and oppression is certainly the first crucial step in gaining a significant degree of freedom for such persons. But the U.N. also estimates that the average stay in refugee camps and "temporary" holding centers for displaced persons is 17 years. ${ }^{5}$ Clearly such persons, who lack core resources but also live in a state of interminable statelessness, are not free, or not sufficiently free. But if so, what steps are needed to complete the process of freeing them from those earlier oppressive conditions, and what is the sense of "freedom" that is being invoked to answer that question?

A particularly unrealistic answer to this question is that they must establish full citizenship in a functioning and just (or nearly just) constitutional democracy. This is either because the nearest locations where those seeing "freedom" can plausibly hope to arrive are not fully functioning democracies, but closer to what Rawls has called "decent hierarchical societies" (Rawls 1999, 64). Such social forms are non-aggressive, respect human rights, and have a generally legitimate and morally oriented legal system (for the most part) but do not afford full rights of democratic participation to all citizens. Often, those fleeing highly oppressive social conditions - that is, they seek freedom from such conditions - can only realistically aim to receive sanctuary in regimes of this sort.

Moreover, many members of migrant communities spend significant parts of their lives as non-citizens (guest workers, temporary residents, even illegal residents) and yet, as I will discuss below, they can in some cases enjoy a relatively secure and meaningful social existence in their communities. This is not to say that such situations are by any means perfectly just, but the concept of freedom should not be tied to such a goal if it is to avoid the charge of overidealization mentioned earlier.

Surely, the language of "freedom" can be used to denote idealized conditions that require equal status in just or nearly just political settings. But understanding the concept only in this way fails to capture the way this idea is used as a primary motivation for most actual people working to escape oppressive conditions, where the discourse of freedom is dominant in their rhetoric, manifestos, songs and statements. What is needed is a conception of basic freedom that captures this use.

However, many standard models of freedom, from liberal negative accounts, to neorepublican views, to Hegelian/Marxist recognition approaches, carry with them statist assumptions that tie the enjoyment of freedom to being a fully sanctioned citizen in stable functioning polities. And as I said, this will pose a special challenge to positive accounts of freedom that tie that condition to political self-government.

With this in mind, let us examine a selection of such frameworks.

\footnotetext{
3 UN Report on International Migration (https://www.un.org/en/development/desa/population/migration/publications/migrationreport/docs/Internation alMigration2019 Report.pdf)

4 UN Report on Refugees: http://www.un.org/en/sections/issues-depth/refugees/

5 UN High Commission on Refugees
} 


\section{Freedom for the Non-citizen: Received Views}

It will not be necessary to survey all of the various models of freedom to make my point here, which is that many influential conceptions of that idea carry with them certain presuppositions regarding citizenship and highly functioning democracies, assumptions that I want, for various reasons, to question. I will briefly touch on negative conceptions and republican models before turning to classical positive ideas, showing that many such conceptions either carry the presupposition in question or, for other reasons, fail to express the idea of freedom at work in the various contexts in which we find it, such as struggles to escape oppressive conditions.

\section{Normative Liberal Conceptions}

Many thinkers in the liberal political tradition have followed John Locke in thinking that "liberty" is conceptually tied to the enjoyment of those rights and privileges that all human beings ${ }^{6}$ enjoy by virtue of their natural rights. ${ }^{7}$ Others may not make reference to natural rights in this way but still define liberty in ways that circumscribe that idea with reference to principles of justice, political morality, or other normative features of social and political life. One is free or deserves to be free, on these views, in the sense of being unhindered from pursuing morally justifiable actions. By extension, freedom in social settings means, on these views, being unobstructed from performing those actions allowed by just institutions.

For example, normative liberal views such as those held by John Rawls and, in a different way, Ronald Dworkin claim that liberty refers to the array of rights and opportunities allowable under adequately justified principles of justice. Hence, one is free only in the sense that one enjoys rights under a just legal order. Of course both Rawls and Dworkin acknowledge the idealized nature of their conceptions of justice, and they both make some mention of the application of their core concepts to non-ideal conditions. ${ }^{8}$ However, in both cases, the idea of liberty (or liberties) being used is conceptualized in a way that refers to the rights and opportunities that would be afforded to members of an established political polity and ties the kind and level of freedom allowable in such settings to membership in these polities.

Now a fully normative conception of freedom is not necessarily alien to the discourse surrounding slaves, refugees and stateless persons even if that idea is explicated in terms of established membership in a nation state, although that context muddies the water quite a bit (as we will see further below with the republican account). It is quite plausible to claim that freedom refers to those rights and prerogatives required by justice (or morality or natural rights) and claim that whatever those rights are, slaves (etc.) are made free only when they are granted them. But first, such views as they are found in the liberal framework typically refer to negative conceptions of liberty - i.e., rights and opportunities - rather than capabilities that enable persons the full exercise of freedom. And I will argue below that such elements are needed. Also, the particular package of rights and liberties that any given regime will sanction will be highly variable and dependent on the historical and social context in which those liberties function. The conception we are seeking is meant to apply across cultural contexts, or at least to settings in

\footnotetext{
6 Arguably, neither Locke nor many other thinkers in this tradition intended "all" here to really refer to all humans. For discussion, see Mills 1991.

7 See John Locke, The Second Treatise of Government.

8 In Dworkin's case, he specifically discusses the application of his idealized conception of liberty to the "real world" of imperfect justice (Dworkin 2000, 172-80). Rawls's extension of his views to non-ideal conditions can be found in Rawls 1999.
} 
which different political institutional structures are in play. Such context-dependent conceptions won't apply here.

For now I merely want to point out for now that the normative accounts found in liberal philosophical theories of freedom refer to political settings with fixed boundaries and membership and with functioning institutions that can or do conform to principles of justice. Extending these accounts to persons who cannot claim such membership will be tendentious at best.

Of course, other liberal theorists define negative liberty in ways that avoid normative implications altogether, defining freedom simply as the absence of constraints on action, neutrally described. The core idea in such a model is to see liberty as the absence of external constraints on one's actions, constraints that are intentionally put in place by others or at least are obstacles whose presence others can be held responsible for. ${ }^{9}$

On these views, degrees of freedom depend simply on the area of action a person is allowed (by others), making no reference to the nature of that area or its importance to the person. Now some defenders of negative liberty, like Matthew Kramer, insist that some reference to values must be made, such that the more a person values the opportunities afforded by absence of constraint, the more free one is. Others have resisted this implication. ${ }^{10}$

However, even admitting that opportunity-freedom of this sort has general value for agents, it is not the kind of value that can explain the profound motivational force that calls for freedom have in the conflict situations I have been considering. Those who label their efforts "freedom struggles" do not simply want more open options of a generic sort, they engage in costly efforts to dismantle specific kinds of barriers to the leading of socially acceptable lives. These aims involve far more general and fundamental alterations in social conditions.

Moreover, the discourses out of which we distill the conception of freedom here clearly do not view that condition as a simple scalar notion, where more freedom is better than less but no major thresholds need be specified as being free, per se. Those fighting for freedom under oppressive circumstances and those fleeing conditions that turn them into refugees or permanent migrants, or those engaged in liberation movements, seek a kind of freedom that is in many ways a condition or state. The language of freedom and liberty across the ages is rife with references to being free, simpliciter - being a free person and being recognized, legally and otherwise, as such. Hence, even if we accept that freedom in one sense is a matter of degree, and indeed that opportunity spaces are one plausible measure of such a vector, another crucial idea that functions in liberation discourses in various social locations refers to an all or nothing condition, one denied to those living in oppressive circumstances. ${ }^{11}$

Of course, one must also be careful that the use of the notion of freedom or liberty in some contexts are not simply synonyms for justice, and that the condition being sought is one of

\footnotetext{
${ }^{9}$ This last point is emphasized by Miller (1983). Others who have developed a view of this sort include Carter 1999, Benn, Kramer 2003, and Steiner 1983.

10 See Kramer 2003 425-43 for discussion.

${ }^{11}$ Admittedly, the history of the language of freedom arises out of times and places where legally designated conditions of being "free" or being a "slave" were part of the political and legal structure of the time. In classical setting such as ancient Greece and Rome, in various parts of Asia and Africa, and in the western hemisphere prior to the late nineteenth century in many places, the law reflected the status of being "free", "freeborn", manumitted (made free), and so on, to be contrasted with being a slave. Hence it could be argued that the categorical conceptualization of freedom inherits this codification, even if the subject is not slavery per se but victims of oppressive circumstances more generally (see Patterson 1982 and 1991). Still, finding a model that makes sense of this usage is an important philosophical aim.
} 
a just or normatively acceptable way of life. Again, if one can explicate the notion of freedom in a way that avoids this implication, one can skirt the objections often brought against such normative accounts.

\section{Republican Freedom}

Another major development in thinking about the idea of freedom is found in attempts by Philip Pettit, Quentin Skinner and others to reclaim the classical republican conception of liberty for use in contemporary settings. In Pettit's version of this view, freedom is defined as nondomination, which means being immune from interferences from other citizens or state institutions that are the product of arbitrary or unilateral decisions by those agents. Arbitrary interferences are those which emanate from a process which does not take adequate account of a person's interests. In contrast with freedom in the opportunity sense just discussed, nondomination means not only a lack of actual interference but also not being subject to possible interference due to the arbitrary whim of another.

\section{As Pettit puts it:}

The promotion of freedom as non-domination requires...that something be done to ensure that public decision-making tracks the interests and the ideas of those citizens whom it affects... It must be a form of decision-making which we can own and identify with; a form of decision-making in which we can see our interests furthered and our ideas respected. Whether the decisions are taken in the legislature, in the administration, or in the courts, they my bear the marks of our ways of caring and our ways of thinking (Pattit 1997a, 184).

This implies that the republican state, for Pettit, will be a constitutional democracy guided by the rule of law, maintain separation of powers, and include strictures on majority rule. Additionally, all state decisions must be "effectively contestable" so that citizens' interests are appropriately tracked by government policy. Contestation will demand effective channels and forums for debate, and discussions will not mirror mere bargaining in that citizens' desires will be shaped by the process itself and not merely exogenously given. Pettit argues that the conditions of non-arbitrariness require that methods of state decision-making be the subject of "common knowledge" and that citizens will see themselves as dominated when entire classes of individuals are afforded lower status than others.

Pettit sums up the core ideas of the republican conception this way:

[E]qual freedom of its citizens, in particular their freedom as non-domination...is the primary concern of the state or republic. The second [idea] is that if the republic is to secure the freedom of tis citizens then it must satisfy a range of constitutional constraints associated broadly with a mixed constitution. And the third idea is that if the citizens are to keep the republic to its proper business then they had better have the collective and individual virtue to track and contest public politics and initiatives. (Pettit 2014, 5)

Clearly, then, freedom in the republican model is tied to official membership in a particular form of state institutional structure. Pettit claims that is view is "non-normative" in that it will be a simple observable fact not an evaluative judgment whether people's interests are being tracked in a way that renders whatever interferences they might be subject to non-arbitrary. I am not at all sure he is correct in that assessment, as the question of arbitrariness will turn not 
merely on whether citizen interests are tracked but whether they are tracked properly. The latter determination is not merely a matter of observation.

Be that as it may, it is clear that being free in the republican sense will require legislative assemblies of a particular sort with deliberative mechanisms for the representation of commonly avowable interests, so that interferences with people's actions will not be arbitrary. This is an ideal that is sometimes, but not often and never completely, realized in the world. In the many places and times when this ideal has not been realized, people lack republican freedom in Pettit's sense and the attainment of such a status will be nowhere on the horizon. But do we want to conclude, then, that freedom is impossible for such people in the foreseeable future and that their aspirations toward such a state are futile or meaningless? While a more detailed treatment of republican freedom on this issue is called for, if we can provide an account of basic freedom that answers this last question in the affirmative, then such a theory will have an advantage over the republican account in properly capturing both the aspirations and the attainment of large classes of persons.

\section{Traditional Positive Accounts}

The tradition of thinking about liberty that most directly ties it to already established membership in well-functioning states is the traditional notion of freedom as self-government, that is the central idea of positive accounts of freedom. I call these views "traditional" since they echo the ancient and enlightenment articulations of the idea that identifies liberty with the status and activities of citizens in self-governing polities. Classical republican accounts display this connection by identifying freedom with the liber of Roman law, a person (man) who is not a slave or otherwise dependent who actively participates in the governing processes of his political community. This status entailed virtues and obligations as well as privileges and immunities. ${ }^{12}$

This is idea is reclaimed in the Renaissance with Machiavelli in his Discourses, where freedom of the person is attached conceptually to the functioning of a free city (state). And this notion is further developed in the Enlightenment period by thinkers such as Rousseau, who conceived of freedom as rule by the general will of which one was a part as a citizen - and not merely represented as such -- in a democracy (republic) governed by the social contract. On this view, freedom is achieved by acquiring equal status with one's fellows in a political association that advances one's interests, considered in light of that association. One is free in that one obeys only oneself, albeit a "self" defined in relation to one's status as a co-member of a selfgoverning community. ${ }^{13}$

This connection between freedom and citizenship is best expressed by the oft-cited lines summing up the project of Rousseau's Social Contract:

...to find a form of associations which will defend and protect with the whole common force the person and goods of each associate, and in which each, while uniting himself with all, may still obey only himself and remain as free as before. (Rousseau 1760/1987: 49)

\footnotetext{
12 Pettit and Skinner argue that the Roman and neo-Roman theorists did not hold a (this kind of) positive conception, where participation is required. But (a) many did interpret them this way, and theorists like Rousseau and Arendt retrieved these ideas with the assumption of participation intact; yet (b) as I will argue in the next section, one can adopt a positive conception of freedom that does not require this sort of participatory citizenship. See Pettit 2002 , Skinner 2012 for discussion of this history.

${ }^{13}$ For a reading of Rousseau that this gloss tracks, see Cohen 2010.
} 
In this way Rousseau connects individual self-government with the collective (rational) selfgovernment of an egalitarian democracy. He thereby epitomizes the thought that freedom requires membership and equal standing in a well-functioning democratic setting.

In his discussion of positive conceptions of liberty, Isaiah Berlin similarly traced how the idea of rational self-government (as a rendering of freedom) led ineluctably to the conception of a free person as a democratic citizen: "Those who believed in freedom as rational self-direction were bound, sooner or later, to consider how this was to be applied not merely to a man's inner life, but to his relations with other members of his society" (Berlin 1969) These connections are developed further: "For if I am rational, I cannot deny that what is right for me must, for the same reasons, be right for others who are rational like me. A rational (or free state would be a state governed by such laws as all rational men would freely accept". (ibid) Hence, freedom in this positive sense cannot be understood apart from one's status as a citizen in a self-governing polity.

The motivation for seeing citizenship, indeed active participation in politics, as a requirement of (positive) freedom picks up on the note sounded by Rousseau and can be found in thinkers such as Hanna Arendt. For Arendt the ideas "liberty" from "freedom" should not be seen as mere synonyms but rather as distinguished by their different relations to citizenship status. On Arendt's view. liberty is akin to liberation and marks escape from oppression; but freedom requires political engagement in a constituted republic. ${ }^{14}$ Only then can the selfgovernment that defines true freedom be realized.

Arendt's (and Rousseau's) conception of self-government requires active control over the conditions of one's social environment enacted through the political institutions of one's place of residence. But this requirement unrealistically assumes the possibility of active control, if not wholesale self-creation, of one's social existence by individuals by way of political structures. This both assumes a level of control over one's embodied social condition that is unrealistic for all persons, but it also, over-narrowly, locates the prime mechanism of that control in formal political institutions. However, one's embodiment, sexuality, familial inheritance, ethnic background, and countless other factors shaping one's outlook and opportunities, cannot be said to be under our control. So why must we require this at the social level? ${ }^{15}$ Secondly, various cultural, social, religious, and family practices will have much more impact on the way one is able to pursue valued ways of life than legal structures will, in many cases.

Rather than assuming liberty means capacity to create and control all aspects of one's social existence, I suggest that freedom requires the acceptance of one's condition, so that the projects and values one pursues can be considered as one's own, in a minimal sense (what I have referred to as "feeling at home"). ${ }^{16}$ As long as one's acceptance is not itself the result of manipulation and constrained circumstances alone, being able to embrace one's individual predicament and social surroundings and embark on valued projects is sufficient for the kind of basic freedom we want to capture here. ${ }^{17}$

As Amartya Sen put it,

\footnotetext{
14 Arendt 1965: 22; cf. also Pitkin 1988.

15 An argument for a parallel point (concerning autonomy) is brought out in more detail in Christman, 2009 , ch. 7.

${ }^{16}$ Cf. David Ingram's citation of Hegel's phrase "being at home with ourselves in an other" in his contribution to this volume.

17 This is to make an oblique reference to the problem of adaptive preferences. For further discussion, see Christman 2014.
} 
"As long as the levers of control are systematically exercised in line with what I would choose and for that exact reason, my 'effective freedom is uncompromised...In modern society, given the complex nature of social organization, it is often hard, if not impossible, to have a system that gives each person all the levers of control over her own life. (Sen 1992, 64-5).

So while more should be said on the matter, I am simply rejecting the semantic point Arendt makes that escape from oppression does not manifest freedom in a crucial sense, one which motivates persons in a fundamental manner and is central to freedom discourse at least since the abolitionist fights in the $19^{\text {th }}$ century. The idea of basic freedom spelled out here is meant to express this very notion. ${ }^{18}$

\section{Basic Freedom}

The outline of a conception of basic freedom to be presented shortly will, I hope, allow us to spell out a conception of liberty that accomplishes the twin goals of capturing the sense of freedom that forms the focal point for those struggling for liberation (better than other competitor notions) and avoids the commitment to citizenship status that most persons involved in such struggles cannot hope for and indeed often do not seek. We will be more precise below, but the general shape of this idea of freedom is this: to be free is to be allowed and enabled to pursue life activities with others that one can value, where, to speak more figuratively, one can feel in a minimal sense "at home". This doesn't mean one will be happy or successful or standing in ideally just relations with others - this is a concept of basic freedom, after all, and it applies to the imperfect world we live in. But freedom here means being in a position to lead a life that has value for the person, given her sense of herself and her social identity.

As we mentioned, countless persons and groups are engaged in struggles to find or reclaim some semblance of a stable home environment after fleeing from, or overthrowing, oppressive conditions from which they are attempting to be freed. This means that millions of people live in conditions of seemingly permanent limbo, suspended between violent persecution, on the one hand, and stable and supportive social locations that they may call (a kind of) home on the other. What is lacking is surely sufficient stocks of basic resources, including nutritional, educational, and housing resources, but also the ability to pursue projects and life plans in a setting that affords them social standing as independent and equal citizens.

One response to the precariousness of these conditions is to argue that securing citizenship status for persons fleeing persecution, whether in a host country or in a reconstituted home state after sufficient reforms are instituted. However, for a number of reasons, such measures are either not realistic in the foreseeable future or are not required for freedom in a sense of that term that captures the aims of those involved. ${ }^{19}$

For example, as others have claimed concerning irregular migrants ${ }^{20}$ social structures can be established within host countries that, while certainly far from ideal, provide a relatively

\footnotetext{
18 For a critical discussion of Arendt's case for the distinction between liberty and freedom, see Pitkin1988.

${ }^{19}$ For example, do we not want to say that Black South African citizens achieved freedom of an important sort when apartheid was overthrown? Nelson Mandela certainly seemed to describe it that way. See Mandela 2008. ${ }^{20}$ See, e.g., Banhabib 2004, chap. 5.
} 
stable social setting within which migrant communities can establish a kind of home. ${ }^{21}$ Nanda Oudejans puts it this way:

[W]ithout denying the deplorable predicament of many unauthorized immigrants (particularly rejected asylum seekers or displaced persons in a refugee context), it should also be noted that irregular immigrants are not always struggling to survive and are not by definition excluded from a normal life. (2019: 448)

Indeed, securing full citizenship status can be counter-productive for some migrants. Oudejans continues:

Indeed, unauthorized immigrants might have something to gain by remaining under the radar and keeping the arm of the (fiscal) state at length, not only because they fear detection, arrest, detention, and removal but also because a life in the periphery gives a certain sense of freedom, autonomy, and economic prosperity. (ibid: 454)

Other analyses bear this out, ${ }^{22}$ though we must be careful not to generalize; for people seeking freedom in their escape from oppressive and debilitating conditions are quite variegated. I am certainly aware that for countless people living under oppressive circumstances or seeking asylum are far from enjoying even basic freedom. And of course gaining citizenship rights will in many cases be an important component of that struggle. But I want at least claim that having such political rights may only bear a contingent connection to the requirements for a "free" social existence, a relation that these claims imply is not always required.

In order to capture the aspirations of persons who lack a sense of home and stable social recognition (as well as resources and protections from persecution), one must, I will argue, see the freedom they aim for in a particular light, one captured by the idea of socially effective agency, a model that includes opportunities as well as enabling conditions and status recognition of a sort that need not presuppose well-established political standing in particular nation states. As such, such a view will have "positive" elements as well as negative ones - capabilities and social status conditions as well as opportunities to act. Let us, then, sketch the basic components of this notion.

\section{Basic Freedom as Effective Social Agency}

In general, the dimensions of freedom I want to sketch fall into the categories of enabling conditions, authenticity conditions, and status conditions mentioned earlier. The first is meant to capture the idea that those who lack basic personal, social and economic resources thereby lack an important dimension of freedom. The second refers to the ways in which one can lack freedom because of internal deprivations and pathologies such as addictions, psychological manipulation, and so on as well as being robbed of social, cultural, and political structures that allow one to live a life of value (where one is "at home"). Finally, freedom also requires that one's standing as a socially recognized candidate for agency by publicly respected. ${ }^{23}$

\footnotetext{
${ }^{21}$ Following Bourdieu, we can say that different forms of social capital can be utilize by groups in securing capabilities and protections that allow them to pursue personal, cultural and work lives that afford basic freedom. See Bourdieu, P. 1986.

22 See, e.g., van Meeteren, et. al. 2009.

${ }^{23}$ These elements mimic points made in other theorists' accounts of freedom, though not any one completely. See, e.g., Gould 1988 and 2013, Honneth 2014, and Sen 1992.
} 
Now we should note that an emphasis on these positive features does not erase completely the relevance of non-interference to freedom. ${ }^{24}$ A positive account of liberty will include requirements of non-interference or non-constraint as a requirement, but on the one hand, it will include a different account of what counts as a constraint and why its absence is important for freedom, and on the other, it will explain why this mere absence cannot capture all of what freedom is when seen as something of fundamental personal and social value.

\section{Enabling Conditions}

One of the longest standing objections to traditional liberal accounts of freedom is motivated by the idea that non-interference fails to account for the ways in which social deprivation and lack of resources can undercut liberty in a systematic way. The idea that freedom requires certain powers and abilities as well as opportunities picks up on Amartya Sen's requirements of agency freedom - namely, the enjoyment of basic capabilities for formulating and pursuing valued functionings. ${ }^{25}$ These include, for example, both the absence of certain disabling conditions as well as access to various resources and social conditions that make decision and choice feasible. ${ }^{26}$

For such an approach to be defensible, a number of challenges must be met. One is that the range of capabilities in question that define freedom must be described in ways that don't reduce to a narrow parochial understanding of human flourishing. Capabilities for the Buddhist monk are different from those of striving business person. ${ }^{27}$ Further, the view should not imply that disabled individuals who have acclimated to their condition and whose environments are such that they are not significantly hampered by them are described as failing to lead flourishing lives simply because of the fact of their "disability". Avoiding such implications is not an easy task and I merely flag them for now. My own view is that the list of basic capabilities will be derivative from the condition of authenticity discussed below, specifically that the basic capabilities that comprise freedom for any individual will be those required for her pursue paths of being and acting sanctioned by her (stable) practical identity.

The challenge, then, is to formulate an account of capabilities which is consistent with a relatively content-neutral (or broadly value-invariant) account of effective agency. These capacities will include both internal and external elements. Physical and psychological disabilities, temporary or chronic inability to form stable intentions and act on them, as well as resources needed to engage in these intentional actions will comprise capabilities in this sense. However, as Sen also argues, the capabilities in question will be specified without conditions of

\footnotetext{
${ }^{24}$ Indeed, one mistake that negative theorists make in criticizing positive notions is to assume that positive theorists, in Kukathas's words, are "not concerned fundamentally with the presence or absence of constraints upon individual action." (1994: 22). Depending on what is meant by "fundamentally", this is inaccurate. For a defender of positive freedom need not think negative notions are incoherent or wrong-headed, but merely that they are incomplete.

${ }^{25}$ Sen gives an abstract rendering of the capabilities in question, namely whatever is required for the valued functionings that are constitutive of a person's being (Sen 1992, chs.3-4). Martha Nussbaum, on the other hand, bases her conception of capabilities on an Aristotelean view of human flourishing (see Nussbaum 2001, 78-82). As will be clear from the text I take a third route, namely a conception of capabilities tied to the person's authentic practical identity.

${ }^{26}$ For an earlier defense of a conception of freedom that ties it to access to resources, see Crocker 1980.

27 This is to depart from the version of the capability view developed by Martha Nussbaum for example (Nussbaum 2001).
} 
success: they are the requirements to pursue valued plans of action, not the successful pursuit of them. In this way, he argues, freedom is distinguished from well-being. ${ }^{28}$

Now it has often been claimed that adding positive requirements of freedom such as capabilities removes the distinction between freedom and, simply, ability or power. The sting of this charge can be removed, I think, if we understand the conditions of unfreedom to count as such only if they have a human source, that is, they are factors either put in place as a result of human activity or are ones that could be feasibly removed by it. ${ }^{29}$ In this way, only when persons are disempowered by other agents, practices, social structures and so on does she lose freedom by that token. Therefore, lack of freedom does not simply correspond with lack of power but only with lack of (a kind of) power whose absence can be traced to social sources. ${ }^{30}$

Further arguments can be offered for the inclusion of such a condition, though I will mention only two here. The first has been much discussed, and it is this: the notion of a constraint cannot plausibly be explicated without reference to the range of abilities that agents have that such constraints inhibit or undercut. A fence is a constraint on freedom of action only if it is high enough to block my path, which means I don't have the ability to easily scale it. And if a reference to abilities is made there, how is it plausible to then claim that a lack of capability (properly defined) is not central to freedom ${ }^{31}$

Second, imagine that the constraints a person suffers under are so severe that they, over time, debilitate her in pronounced ways; say the chains that bind one are on so long that one's muscles atrophy, so that when they are removed, one lacks the ability to move one's limbs effectively. Would not this disability be counted as a lack of freedom, even if it is in some way an inability at that point? If so, then the line between lacking a power/ability and lacking freedom (in the opportunity sense) is already blurry, so the claim that inclusion of capabilities in one's account is counterintuitive lacks force.

As I said, this discussion of capabilities is overly brief but it connects to the second dimension of positive freedom I want to defend, that of being enabled to pursue authentic projects as an effective agent in social space.

\section{Authentic Agency}

Recall that we are asking what freedom might mean as an aspiration for those forced to flee their homes and in search of stable living situations, either back in one's homeland or in a new community. Before this is achieved, we can note that a key feature of life for such persons is deep and abiding alienation from their surroundings as long-term settings in which to pursue their lives. Of course such alienation is hardly limited to refugees and migrants. The extremely poor, those forced into labor situations against their will, victims of discrimination and social

\footnotetext{
28 Or as he puts it: agency freedom is distinguished from well-being freedom. See Inequality Reexamined. Also, Now some have objected that freedom-as-capability removes the unique character of freedom as a phenomenon and a value. This is because, allegedly, capability-freedom reduces the value of being free to the value of accomplishing goals. See, e.g., Carter Measure 127 (see also pp. 56-8). I attempt to respond to this problem in Christman (2012). For an overview see Robeyns 2011.

${ }^{29}$ This bears some affinity to the "responsibility" view of constraints defended in different ways by Miller 1989 and Kristainsson 1996, chap. 6.

30 Cf. Pettit (2012), who claims that one lacks freedom when one's lack of resources (in my case capabilities) can be traced to the actions of other persons (Pettit 2012, 41-44).

31 As I said, this point has been much discussed, and I don't pretend to state this argument in a way that settles the issue. I merely want to gesture at the kinds of considerations that motivate this conditions. See, e.g., Carter 2003, section 5 .
} 
marginalization, often cannot view their life options as minimally valued from their own settled perspective. The modes of life, activities and plans that such a person has open to her are (we can imagine) of such paltry character that she lacks sustained motivation to engage in them, except perhaps as a matter of survival (or for the care of others). ${ }^{32}$

This last point is, I think, the fulcrum upon which to center the account of authenticity required for freedom, namely that the agent is able and allowed to pursue modes of being that she can see as minimally worth pursuing from her own reflective perspective. To use familiar terminology from another context, such modes of being will be sanctioned from the perspective of her practical identity. ${ }^{33}$ That is, the self-understanding by which a person sees her life as worth living and which grounds her motivations and plans amounts to an evaluative perspective that organizes and guides her choices. The authenticity condition picked out here is merely that the options open to the person are ones that can be sanctioned from that perspective. ${ }^{34}$

We need also to point out the irreducibly social elements that structure this practical identity. One's value orientation makes essential reference to ways of life, not merely isolated choices, and such ways of life virtually always have historical constituents as well, so that one's identity is shaped by social practices, traditions, religion, and cultural dynamics that cannot simply be constructed or recreated by one's own efforts. Social settings largely define what is minimally valuable for a person to pursue. In this way, freedom requires a basic sense of being "at home" in the world. ${ }^{35}$

This is the crucial point here. For the requirements of freedom laid out here include having opportunities and capabilities that allow one to live out a social existence that one can accept - see has constitutive of a meaningful existence - not that one necessarily fully controls or is the author of. I posit this in order to capture the ways that all our lives, the privileged and the deprived, are shaped by forces that did not originate with us and which we cannot, except at the margins, control. Yet for the fortunate among us, we can embrace these conditions are an acceptable structure within which a meaningful existence, including choices such a structure allows within itself, can be pursued. ${ }^{36}$

And again, one's political status as a citizen or permanent resident or guest worker (and so on) will be contingently related to this ability to accept one's social condition, to "feel at home" in the world. This involves functioning in a linguistic community, finding meaningful work and life activities, engaging in caring relations, and so on. Whether one's ability to find

\footnotetext{
32 Cf. Raz's claims regarding the requirement for autonomy, namely the adequacy of options faced by the agent (Raz 1986 375). However, Raz gives little guidance to what such adequacy amounts to, except to say that such a range must enable the person to exercise "all the capacities human beings have an innate drive to exercise". He also claims that such a range must include choices with long term consequences as well as short-term effects; and it must include enough variety to allow the person to exercise discernment in guiding her life by her own lights (Raz, ibid.).

33 See Korsgaard 1996.

34 In other contexts, I have discussed authenticity in a similar vein as a condition of autonomy. The requirement is similar in this context, but freedom, even in its positive form, is not equivalent to full-scale self-government. Nor is the idea of authenticity here connected to identification with (or non-alienation from) first order motives as part of a life narrative, as I have claimed autonomy demands. See Christman 2009: chap. 8.

35 See Gould 2013, esp. 109, who makes very similar points.

36 Moreover, tying freedom to one's practical identity in this way will allow us to give a better account of what constraints should be counted as limitations on freedom. For unlike the neutral counting of standard negative models, a constraint only counts as such for us if it frustrates the successful performance of a course of action deemed worth pursuing from one's (stable) practical perspective.
} 
such a social location and live within it may depend on having a political voice in the centralized state institutions that govern one's living area; but (importantly) it may not. And there is no conceptual necessity that one stand as a political member of the broader community that shapes that existence. For the reasons I have been laying out, I take this as a particular advantage of this account.

This discussion of authentic value orientations will help further show why limitations on freedom should not be confined simply to constraints simply on action as such. For when one is not recognized as an agent with an authentic value orientation at all, or as a deficient or degraded version of an agent, one lacks freedom independently of what actions one is allowed to undertake viewed narrowly.

\section{Status and Recognition}

Many writers developing positive conceptions of liberty have stressed that interactions with others can support or undercut freedom in direct ways, specifically that one can be rendered unfree due to lack of proper recognition by significant others in a way that both engages the intersubjective structure of thought and intention as well as affords the person with the standing as an agent encountering other agents on those terms. ${ }^{37}$

I agree that the kind of freedom fought for in abolitionist struggles and migratory quests for home and the like (which I am using as the touchstone for this analysis) requires that one has a kind of standing in a community as a person worthy of freedom. Relegating persons as dispensable or as sub-human or as enslavable implies that freedom does not apply to them, their effective social agency is not a pressing concern. ${ }^{38}$

Consider conditions where groups are subject to pervasive derogatory attitudes that essentially prevent them from living in public as themselves (without facing such degradation). Persons facing such discrimination are thereby regarded as unworthy of full participation in the social and political world in which they reside. ${ }^{39}$ Racist attitudes can prevail to an extent that undercuts effective agency long after nominal legal protections are put in place to prevent overt interference and constraint. And when this is the case, people are prevented from engaging in socially effective agency, simply because they are denied the social resources required to be the kind of person they identify as, in public and without shame. ${ }^{40}$ For these reasons I suggest that a condition of social status whereby a person is publicly treated as a candidate for free agency is required for freedom itself. This follows from the view developed so far of effective agency, without relying on a full commitment either to Hegelian conceptions of agency, object relations theory in psychology, or other such theoretical foundations adopted by others to require recognition for freedom. ${ }^{41}$

\footnotetext{
37 See, e.g., Honneth 2014.

38 I have argued elsewhere, however, that that terms under which persons are described that ground this recognition must be determined by the persons themselves, and not given either a priori or by the dominant groups in a society (Christman 2020).

39 Pettit argues that (neo-) republican freedom reconnects that notion to a guarantee of honor and hence restores the status requirement to the idea of liberty. On the republican account, a person is free if she is not subject to the arbitrary will of another, if she is not dominated. Pettit 1997: 64. However, this describes a merely contingent connection between freedom (as not being subject to arbitrary interference) and one's status as a person able to conduct her own affairs with the abiding acknowledge by others of her capacity to do so.

40 Cf. Amartya Sen's defense of a similar consideration: Sen 1992.

41 That is, this view departs from similar claims made by Honneth (in Honneth 2014).
} 
Also, and more to the present point, enjoying the socially recognized status of being a free person is defended because of its ties to one's ability to engage in minimally valued pursuits. This may not require being a citizen or an active participant in institutionalized politics. That depends on the contingencies of one's circumstance: when lack of political status and the related control undercuts one's ability to pursue valued aims, then citizenship is required for freedom. But when can stand in social space with dignity and accept one's opportunities for pursuing a valued life without the status of citizen (as is sometimes the case), then citizenship is not required for basic freedom.

\section{Conclusion}

In this essay, I have attempted two related things. The first was to challenge the idea that freedom and citizenship should be conceptually tied together. I had two sets of reasons for doing this: First, freedom in the sense of being able to live a life of one's own does not require in all cases the kind of direct political control that citizenship and advanced democratic practices enable, valuable though those things are. Second, assuming citizenship in one's idea of freedom fails to capture the discursive logic of countless people whose life situation and long-term prospects do not include citizenship in fully- or nearly-just democracies.

My second objective here was to sketch the major elements of a positive conception of liberty that avoids the presupposition of citizenship. Of course, this is merely a sketch. For now, however, I merely want to paint the general picture of what freedom in a positive sense might look like in order to capture the value in question as it motivates those struggling so desperately to achieve it. 


\section{$\underline{\text { References }}$}

Arendt, H. (1965) On Revolution. New York: Viking Press.

Arneson, R. J. (1985) “Feedom and Desire” Canadian Journal of Philosophy, 3: 425-48.

Benhabib, S. (2004) The Rights of Others: Aliens, Residents, and Citizens. Cambridge:

Cambridge University Press.

Benn, S.I. (1988) A Theory of Freedom. Cambridge: Cambridge University Press.

Berlin, I. (1969) 'Two Concepts of Liberty', in I. Berlin, Four Essays on Liberty, London: Oxford University Press.

Bourdieu, P. (1986) "The Forms of Capital.' In Handbook of Theory and Research for the Sociology of Education. Ed. J. G. Richardson. New York: Greenwood. Pp. 241-258.

Carter, I. (1999) A Measure of Freedom, Oxford: Oxford University Press. --- (2003) "Positive and Negative Liberty" Stanford Encyclopedia of Philosophy http://plato.stanford.edu/entries/liberty-positive-negative/

Christman, J. (2009) The Politics of Persons: Individual Autonomy and Socio-historical Selves. Cambridge: Cambridge University Press.

--- (2012) “Can Positive Liberty Be Saved?” in Steven M. Cahn and Robert B. Talisse, eds. Political Philosophy in the 21st Century: Essential Essays, Boulder, CO: Westview Press, 155-68.

--- (2014) "Coping or Oppression: Autonomy and Adaptation to Circumstance" in Andrea Veltman and Mark Piper, eds., Autonomy, Oppression and Gender (New York: Oxford University Press: 201-26.

--- (2020) "What if Anything is Wrong with Positive Liberty? The Struggles of Agency in a Non-Ideal World" in Daniel Weinstock, Jacob T. Levy and Jocelyn Maclure, eds. Interpreting Modernity: Essays on the Work of Charles Taylor. Montreal, CA: McGillQueens University Press: 95-113.

Cohen, J. (1986) “Autonomy and Democracy: Reflections on Rousseau” Philosophy and Public Affairs 15: 275-97.

--- (2010) Rousseau: A Free Community of Equals. Oxford: Oxford University Press.

Crocker, L. (1980) Positive Liberty. Hingham, MA: Kluwer Boston.

Dworkin, R. (2000) Sovereign Virtue. Cambridge, MA: Harvard University Press.

Gould, C. (1988) Rethinking Democracy: Freedom and Social Cooperation in Politics, Economy, and Society. New York: Cambridge University Press.

--- (2013) "Retrieving Positive Freedom" in Bruce Baum and Robert Nichols, eds. New York: Routledge: 102-113. 
Honneth, A. (2014) Freedom's Right: The Social Foundations of Democratic Life. New York: Columbia University Press.

Korsgaard, C. M. (1996) The Sources of Normativity New York: Cambridge University Press.

Kukathas, C. (1994) "Defending Negative Liberty” Policy (Winter): 21-26.

Kramer, M. H., (2003) The Quality of Freedom, Oxford: Oxford University.

Kristjansson, K (1996) Social Freedom (Cambridge: Cambridge University Press.

Mandela, Nelson (1008) The Long Walk to Freedom: The Autobiography of Nelson Mandela. New York: Little Brown.

Miller, D. (1983) 'Constraints on Freedom', Ethics, 94, pp. 66-86.

--- (1989) Market, State and Society. Oxford: Oxford University Press

Mills, C. (1997) The Racial Contract. Ithaca, NY: Cornell University. ---(2005) “'Ideal Theory' as Ideology” Hypatia 20, no. 3 (Summer): 165-84.

Nussbaum, M. (2001) Women and Human Development: The Capabilities Approach. Cambridge: Cambridge University Press.

Oudejans, N. (2019) “The Right Not to Have Rights: A New Perspective on Irregular Immigration”. Political Theory 47 no. 4: 447-74.

Patterson, O. (1982) Slavery and Social Death: A Comparative Study. Cambridge, MA: Harvard University Press.

--- (1991) Freedom: The Making of Western Culture. London: I.B. Tauris.

Pettit, P. (1997a) Republicanism: A Theory of Freedom and Government. Oxford: Oxford University Press.

--- (1997b), "Freedom With Honor: A Republican Ideal” Social Research 53, no. 1 (Spring): 52-76.

--- (2002) 'Keeping Republican Theory Simple: On a Difference with Quentin Skinner" Political Theory 30, no. 3 (June): 339-56.

--- (2012) On the People's Terms: A Republican Theory and Model of Democracy.

Cambridge: Cambridge University Press.

--- (2014) Just Freedom: A Moral Compass for a Complex World. New York: Norton.

Pitkin, Hanna (1988) “Are Freedom and Liberty Twins” Political Theory. 16, no. 4 (November): 523-52.

Rawls, J. (1971) A Theory of Justice. Cambridge, MA: Harvard University Press.

--- (1999) The Law of Peoples. Cambridge, MA: Harvard University Press.

Raz, J. (1986) The Morality of Freedom. Oxford: Oxford University Press. 
Robeyns, I. (2011) “The Capabilities Approach” Stanford Encyclopedia of Philosophy, http://plato.stanford.edu/entries/capability-approach/\#SpeCapApp.

Rousseau, J.-J. (1760/1987) (1987) Basic Political Writings. D. Cress, ed. Indianapolis, IN: Hackett.

Sala-Molins, L. (2006) Dark Side of the Light: Slavery and the French Enlightenment, John Conteh-Morgan,trans. Minneapolis, MN: University of Minnesota Press.

Sen, A. (1985) 'Well-being, Agency and Freedom', Journal of Philosophy, 82: 169-221. --- (1992) Inequality Reexamined, Oxford: Oxford University Press.

Simmons, A. J. (2010) "Ideal and Non-Ideal Theory" in Philosophy \& Public Affairs 38, no. 1: 5-36.

Skinner, Q. (2012) Liberty Before Liberalism. Cambridge: Cambridg University Press.

Steiner, H. (1983) "How Free: Computing Personal Liberty”, in A. Phillips Griffiths, Of Liberty, Cambridge: Cambridge University Press. --- (1994) An Essay on Rights, Oxford: Blackwell.

Stemplowska, Z. (2008) "What's Ideal About Ideal Theory?" Social Theory and Practice (34, no. 3 (July): 319-340.

Taylor, C. (1979) “What's Wrong with Negative Liberty?", in A. Ryan (ed.), The Idea of Freedom, Oxford: Oxford University Press.

Van Meeteren, M. (2009) "Striving for a Better Position: Aspirations and the Role of Cultural, Economic, and Social Capital for Irregular Migrants in Belgium" International Immigration Review 43 no. 4 (Winter): 881-97. 
Notes 